\title{
RESEPSI KONSEP MENUTUP AURAT DALAM TRADISI PEMAKAIAN “RIMPU" (STUDI LIVING QUR'AN-HADIS DI DESA NGALI, KEC. BELO, KAB. BIMA-NTB)
}

\author{
Nurul Karimatil Ulya \\ Program Magister Ilmu Al-Qur'an dan Tafsir \\ UIN Sunan Gunung Djati Jl.Cimencrang, \\ Bandung 40614, Indonesia \\ E-mail: Nurulkarimati195@gmail.com
}

\begin{abstract}
This article tries to discuss the discourse of the necessity of the application of the living Qur'an-Hadith method towards "Rimpu" tradition in Ngali village, a part of Bima regency in West Nusa Tenggara with the theory of Sociology of knowledge offered by Karl Mannheim. "Rimpu" is an unique tradition from Bima ethnic that concept to cover aurah (part of women's body) by wear "Rimpu". In conclusion, the efforts of the initiators of the living Qur'an-Hadith to make it be one approach and partners in the study of the Qur'an and Hadith in society that needs to be appreaciated, and the goal is to develop Islamic Studies. The reception of the Qur'an and Hadith toward the culture of Islamic society (particularly the "Rimpu' tradition among Bimanese) with the theory Sociology of Knowledge is a method of reception of the results of elaboration. If this theory applied in the reception of the living Qur'an-Hadith, it will produce a relative interpretation, or tentative interpretation, and dynamic one that always demands a change in accordance with the age, social and cultural backgrounds. Its implication that Qur'an and Hadith will always in the heart of Muslim everywhere and manifest in their activities.
\end{abstract}

Keywords:

Living Qur'an-Hadith; Rimpu Tradition; Sociology of Knowledge; Reception.

\begin{abstract}
Abstrak
Tulisan ini membahas sebuah wacana ilmiah tentang urgensi aplikasi metode Living Qur'an-Hadis terhadap tradisi pemakaian "Rimpu" di Desa Ngali, sebuah desa yang berada di Kabupaten Bima, provinsi Nusa Tenggara Barat dengan teori "Sociology of Knowledge" yang dikembangkan oleh Karl Mannheim. "Rimpu" adalah sebuah tradisi unik yang berada di masyarakat Bima yang mengkonsepkan penutup aurat bagi wanita Muslim dengan menggunakan "Rimpu". Hasilnya, usaha yang dilakukan oleh para penggagas metode Living Qur'an-Hadith di masyarakat ini mestinya diapresiasi karena memberikan kontribusi terhadap khazanah keilmuan Islam. Adapun resepsi Al-Qur'an dan Hadis terhadap tradisi Islami yang berkembang di tengah masyarakat (khusunya "Rimpu" bagi masyarakat Bima) dengan teori "Sociology of Knowledge" adalah sebuah metode resepsi hasil elaborasi. Jika teori ini diaplikasikan dalam memberikan resepsi Al-Qur'an dan Hadis, maka hal ini akan memunculkan sebuah intepretasi yang relatif dan berkembang dinamis seiring dengan perkembangan zaman, sosial, dan budaya yang melatarbelakanginya. implikasinya adalah bahwa Al-Qur'an dan Hadis akan selalu ada dalam hati umat Muslim yang dimanifestasikan dalam aktivitas sehari-hari.
\end{abstract}

Kata Kunci:

Living Qur'an-Hadis; Tradisi Rimpu; Sosiologi Pengetahuan; Resepsi.

\section{A. PENDAHULUAN}

Pembahasan tentang perempuan dalam Al-Qur'an dan Hadis merupakan salah satu dari sekian persoalan kompleks dan seakan tidak ada habisnya untuk dikaji, mulai dari persoalan jasmani, rohani, hak dan kewajiban hingga eksistensinya di ranah publik. Isma'il Abdul Fatah dan Fauzi Muhammad al-Sa'id dalam kitab Huqūq al-Mar'ah fi al-Islām, secara umum membagi hak-hak perempuan berdasarkan perannya, meliputi sebagai seorang istri, ibu, anak, saudara, nenek atas haknya terhadap hukum, sosial, ekonomi, dan lain-lain. ${ }^{1}$ Hal ini menandakan bahwa Islam

1 Isma'il 'Abdul Fatah 'Abdul Kafi dan Fauzi Muhammad al-Sa'id 'Atwah, Huqūq al-Mar'ah fi al- 
sangat memperhatikan kondisi perempuan agar selalu terjaga dan terlindungi kemuliaannya. Salah satu upaya untuk merealisasikan harapan tersebut, yakni dengan adanya anjuran untuk menutup aurat bagi perempuan muslim yang telah 'áqil balig.

Menutup aurat dalam realitanya dipahami dan diimplemantasikan dengan beragam. Bukan hanya menjadi persoalan penerapan syari'at, melainkan juga karena dipengaruhi oleh tradisi dan kebudayaan yang berbeda antara negara/wilayah yang satu dengan lainnya. Meski begitu, keragaman tersebut tidak bermaksud untuk memudarkan atau bahkan menghilangkan tujuan dan esensi dari menutup aurat itu sendiri. Hal ini justu menarik untuk dikaji lebih jauh, karena perbedaan merupakan rahmat-Nya. Allah SWT. Berfirman :

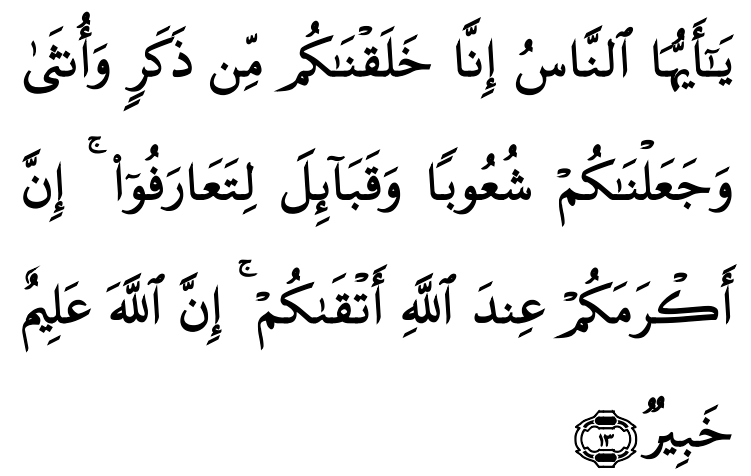

"Hai manusia, Sesungguhnya Kami menciptakan kamu dari seorang laki-laki dan seorang perempuan dan menjadikan kamu berbangsa - bangsa dan bersukusuku supaya kamu saling kenal-mengenal. Sesungguhnya orang yang paling mulia diantara kamu disisi Allah ialah orang yang paling taqwa diantara kamu. Sesungguhnya Allah Maha mengetahui lagi Maha Mengenal." (QS. Al-Hujurat [49]: 13)

Kewajiban menutup aurat berlaku untuk laki-laki dan perempuan. Namun, pada buku ini akan lebih banyak pembahasan tentang aurat perempuan yang akan akan dibahas pada bab selanjutnya secara detail. Adapun latar belakang anjuran menjaga aurat ini

Islām (t.t.: Ṭabaqa Liqawāni al-Mulkiyyah alFikriyyah, t.th.), 14. sebagaimana ditegaskan oleh sabda Nabi Muhammad SAW.:

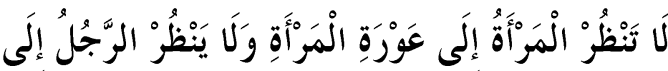

$$
\begin{aligned}
& \text { عَوْرَة الرَّجُل }
\end{aligned}
$$

"Janganlah seorang wanita melihat aurat wanita lain, dan janganlah seorang lelaki melihat aurat lelaki lain." (HR. Ibnu Majjah) ${ }^{2}$

Aurat menurut Muhammad ibn Abu Bakar al-Razi dalam kitabnya Mukhtär alSihah adalah aurat manusia dan semua hal yang menyebabkan malu. ${ }^{3}$ Sedangkan menurut Ibnu Manzur dalam Lisān al-'Arab, kata aurat diartikan sebagai setiap aib atau cacat cela pada sesuatu, dan sesuatu itu tidak memiliki penahan (penjaga). ${ }^{4}$ Ketika sebuah perintah dikeluarkan sejatinya perintah itu bersifat wajib untuk diikuti. Kemudian apabila kewajiban tersebut ditinggalkan, maka tentu ada konsekuensi yang akan mengiringinya. Dalam Hadisnya, Nabi SAW. bersabda tentang keadaan penduduk neraka yang salah satunya dihuni oleh perempuan yang tidak sempurna dalam menutup auratnya :

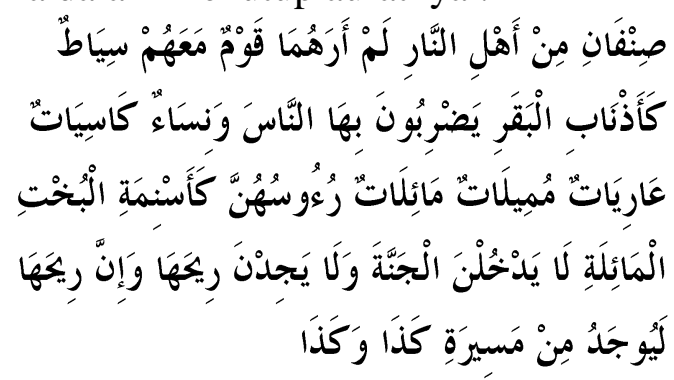

"Dua golongan penghuni neraka yang belum pernah aku lihat; kaum membawa cambuk seperti ekor sapi, dengannya ia memukuli orang dan wanita-wanita yang berpakaian (tapi) telanjang, mereka berlenggak-lenggok dan condong (dari

\footnotetext{
2 Ibnu Majah, Sunan Ibnu Majjah, Kitab Thaharah dan sunah-sunahnya, Bab Larangan melihat aurat saudaranya, No. Hadist 653. CD Ensiklopedi Hadis Kitab 9 Imam (t.t: Lidwa Pustaka i-Software, t.th.).

${ }^{3}$ Muhammad ibn Abi Bakar al-Razi, Mukhtär alSihah, editor Mahmud Khatrabik (Beirut: Dar al-Fikr, 1973), 461.

4 Ibnu Manzur, Lisān al-'Arab, Juz IV (Beirut: Dar al-Shadir, 1992), 616.
} 
ketaatan), rambut mereka seperti punuk unta yang miring, mereka tidak masuk surga dan tidak akan mencium baunya, padahal sesungguhnya bau surga itu tercium dari perjalanan sejauh ini dan ini." (HR. Muslim dan Ahmad)

Beberapa ayat dalam Al-Qur'an dan Hadis menunjukkan spesifik batasan aurat yang benar sesuai syari'at, bahkan ditegaskan secara langsung dalam berbagai istilah/terminologi pakaian penutup aurat itu sendiri ${ }^{6}$. Di era Globalisasi saat ini, perkembangan fashion sangat diminati, terutama fashion muslim. Berbagai mode/style penutup aurat, seperti jilbab, kerudung, maupun pakaian muslimah lainnya tergolong pesat dan variatif. Tak heran kemudian bisnis fashion ini begitu menjanjikan. Uniknya, ada fakta bahwa Indonesia sebagai negara dengan beragam ras, suku, budaya dan agama ini juga mempunyai gaya fashion hijab yang tradisional dan historikal.

Misalnya pakaian tradisional "Rimpu" yang ada di Bima-Dompu (Baca: Suku "Mbojo"). Menurut catatan sejarah yang tertulis dalam kitab Bo' Sangaji Kai, yang disunting oleh Henry Chambert-Loir dan Siti Maryam R. Salahuddin (Putri "Ruma Rato" Kerajaan Bima), bahwa sekitar tahun 1050 H/1631 M, pernah berdiri dan berjaya sebuah kerajaan Islam dibawah kepemimpinan Sultan Abdul Kahir (1631-1640 M) sebagai Sultan pertama. Kerajaan Bima merupakan salah satu

5 Muslim, Sahih Muslim, Kitab Pakaian dan perhiasan, Bab Wanita berpakaian tetapi telanjang, No. Hadis 3971. Lihat pula Ahmad, Musnad Ahmad, Kitab Sisa Musnad sahabat yang banyak meriwayatkan Hadis, Bab Musnad Abu Hurairah Radliyallahu 'anhu, No. Hadis : 8311. CD Ensiklopedi Hadis Kitab 9 Imam (t.t: Lidwa Pustaka i-Software, t.th.).

6 Konsep penutup aurat dalam Al-Qur'an diistilahkan dengan khimār, jalābīb, șiyāb, libās, dan sarābìl. Lihat QS. An-Nūr [24] : 31, 58 dan 60, QS. AlAhzāb [33] : 59 dan 53, QS. Al-A'rāf [7]: 26-27, QS. An-Nahl [16] : 81 dan 112, QS. Al-Furqān [25] : 47, QS. Al-hajj [22] : 19 dan 23, QS. Fațir [35] : 33, QS. An-Naba [78] :10, QS. Al-Anbiyā' [21] : 80, QS. AlKahfi [18] : 31, QS. Al-Muddașșir [74] : 4, QS. Hūd [11] : 5, QS. Nūh [71] : 7, QS. Ibrāhīm [14] : 50. kerajaan dengan penerapan syari'at Islam yang kuat. Dalam berbagai kebijakannya, sang Sultan beserta pejabat istana mengacu pada Al-Qur'an dan Hadis sebagai pedoman hidup umat manusia. ${ }^{7}$ Ditambahkan Siti Lamusiah, ada semboyan yang sejak dahulu dijunjung oleh masyarakat Bima, yakni "Mori ro made na Dou Mbojo ede kai hukum Islam-ku”, yang artinya "Hidup dan matinya orang Bima harus dengan hukum Islam", yaitu Al-Qur'an dan Hadis itu sendiri. ${ }^{8}$ Salah satu buktinya adalah tradisi Rimpu sebagai implementasi adanya perintah menutup aurat bagi perempuan dalam Al-Qur'an dan Hadis, bahkan menjadi ketetapan dan aturan resmi Kesultanan Bima pada waktu itu.. Menurut MR Pahlevi Putra N.I. Singke, Rimpu dalam pengertiannya adalah pakaian yang menutupi aurat atau semua anggota tubuh perempuan dengan menggunakan kain sarung khas (Tembe Nggoli). ${ }^{9}$ Umumnya, Rimpu terbagi menjadi dua macam, yakni Rimpu Mpida, yang digunakan oleh remaja/gadis yang belum menikah dengan seluruh bagian tubuh tertutup kecuali kedua mata, serta Rimpu Colo yang digunakan oleh perempuan yang sudah berkeluarga dengan tubuh tertutup kecuali wajah. $^{10}$

Selain itu, adanya tradisi Rimpu ini juga tidak terlepas dari peranan Lebe (baca: ulama). Keberadaan Lebe telah ada sejak zaman berdirinya Kerajaan Bima hingga saat ini. Lebe pada masa kerajaan berposisi sebagai dewan atau penasihat dalam Badan Hukum

7 "Naskah Yayasan Samparaja", dalam Henri Chambert-Loir dan Siti Maryam R. Salahuddin (penyunting), Bo' Sangaji Kai : Catatan Kerajaan Bima, Edisi II (Jakarta: Yayasan Pustaka Obor Indonesia, 2012), 44.

${ }^{8}$ Siti Lamusiah, "Estetika Budaya Rimpu pada Masyarakat Bima : Kajian Religiusitas", Jurnal Media Bina Ilmiah, Vol. 7, No. III, Mei 2013, 19-20.

${ }^{9}$ MR Pahlevi Putra N.I. Singke, Salungka Pa'a : Ragam Hias Kain Tradisional Masyarakat Dompu Kultur Kain Tenun Songket Dompu (Lombok: CV Rossamari Sentausa, 2011), 11.

${ }^{10}$ Manggaukang Raba dan Mars Ansory Wijaya, Dompu : Dulu, Kinii dan Esok (Mataram: UD Bugenvil, 2002), 64. 
Syara' Dana Mbojo (dalam istilah sekarang bentuknya seperti Majelis Ulama Indonesia). Lebe tersebut tersebar di 18 wilayah di Bima, yaitu Lebe Dalam, Talabiu, Sape, Sila, Ngali, Wera, Wawo, Sakuru, Samili, Teke, Dena, Sumi, Raba Keli, Parado, Karumbu, Cenggu, Raba Ngodu, dan Mbawa. ${ }^{11}$ Seiring berjalannya waktu, keberadaan Lebe semakin berkurang karena usia dan banyak yang sudah wafat. Namun, beberapa Lebe ada yang masih hidup masih berperan sebagai tokoh agama sekaligus tokoh masyarakat yang sangat disegani dan dihormati oleh masyarakat Bima, tempat masyarakat menimba ilmu agama Islam.

Oleh sebab itu, fenomena ini akan dibahas sebagai fokus kajian pada bagian pembahasan dalam tulisan ini, yakni bagaimana relevansi konsep menutup aurat dalam Al-Qur'an dan Hadis terhadap nilai tradisi pemakaian Rimpu oleh masyarakat Bima.

\section{B. PEMBAHASAN}

\section{Konsep Menutup Aurat dalam Islam}

Menurut Fuad Mohd Fahruddin, asal kata "aurat" merupakan serumpun dari kata 'awira (عور ) yang berarti kehilangan satu mata, maka berarti mata yang hilang cahayanya. Pada umumnya kata ini memberi arti tidak baik dan dipandang memalukan. Juga kata 'āra (عار) berarti menutup atau menimbun sehingga tidak dapat dilihat atau dipandang. Dan kata a'wara (أعور) sebagai sesuatu yang jika dilihat akan mencemarkan sehingga harus ditutup agar tidak menimbulkan kekecewaan dan malu. ${ }^{12}$ Sedangkan kata 'awrah (عورة) dalam kamus "Al-Mawrid" diartikan sebagai cacat, kerusakan atau aib. ${ }^{13}$ Istilah aurat ini sebenarnya telah ada pada masa awal penciptaan Adam dan Hawa yang dikisahkan

11 Henri Chambert-Loir dan Siti Maryam R. Salahuddin (penyunting), Bo' Sangaji Kai..., 606.

${ }^{12}$ Fuad Mohd Fahruddin, Aurat dan Jilbab dalam Pandangan Mata Islam (Jakarta: Pedoman Ilmu Jaya, 1991), 1-2.

${ }^{13}$ Rohi Baalbaki, Al-Mawrid : A Modern ArabicEnglish Dictionary, Cet. VII (Beirut: Dar el-Ilm Lilmalayin, 1995), 787. dalam Al-Qur'an terbujuk tipu daya Iblis untuk mendekati dan memakan buah terlarang yang diharamkan Allah untuk dimakan sehingga mengakibatkan keduanya diusir oleh Allah dari surga dan turun ke bumi. ${ }^{14}$

Dalam sejarah perkembangannya pakaian yang berfungsi untuk menutup aurat ini tidak hanya dikenal oleh agama Islam dan masyarakat Arab saja. Di kota-kota tua seperti Mesopotamia dan Babylonia, pakaian yang menutup aurat ini berfungsi sebagai identitas perempuan yang berstrata sosial kelas menengah atas. Selain di kota-k/ota tersebut, wacana ini juga sempat berkembang dalam Code Bilalama (3.000 SM), Code Hammurabi (2.000 SM), Code asy-Syiria (1.500 SM) serta Kerajaan Persi (500 SM). ${ }^{15}$

Sedangkan dalam ranah keagamaan, konsep pakaian penutup aurat ini juga diberlakukan pada semua agama Samawi dan agama lainnya dengan latar belakang dan motivasi masing-masing. Pada literatur Yahudi misalnya, telah dikenal istilah "Jilbab" dan penggunaannya yang berawal dari kisah dosa asal, yakni dosa Hawa yang menggoda suaminya Adam untuk memakan buah terlarang. Akibatnya, ia mendapatkan kutukan yang hingga kini diturunkan kepada anak dan keturunan perempuannya, yaitu beban kehamilan, sakit sewaktu melahirkan, mengeluarkan darah menstruasi, rasa sakit dalam darah keperawanan, susah-payah merawat anak, keharusan menutup kepala, sakit sewaktu melubangi telinga agar dapat memakai perhiasan (anting-anting), tidak dipercaya sebagai saksi dan terjadinya kematian. Kutukan ini disebut "9 Kutukan Perempuan" yang diyakini kebenarannya oleh kepercayaan Yahudi. ${ }^{16}$

Selain agama Yahudi, agama Nasrani (Kristen) juga meyakini dan menganggap jilbab sebagai simbol ideologi dan ketaatan

${ }^{14}$ Lihat QS. Al-A'rāf [7]: 19-37.

15 Nasaruddin Umar, Antropologi Jilbab, dalam Jurnal “Ulumul Qur'an” No. 5, vol. VI, 1996, 39.

${ }^{16}$ Leonard J. Swidler, Woman in Yudaism : The Status of Women in Formatice Yudais (Metuchen: Scare Crow Press, 1978), 115. 
seseorang. Hal ini tercantum dalam "Alkitab" yang berbunyi:

"Seseorang perempuan yang berdo'a dengan kepalanya tidak berjilbab berarti tidak menghormati kepalanya- sama dengan kepalanya dipotong. Karena jika perempuan tidak menjilbabi dirinya, maka hendaknya dia memotong rambutnya, tetapi jika bercukur itu memalukan untuk seorang perempuan, maka pakailah jilbab. Untuk seorang laki-laki dari tuhan; tapi perempuan adalah kebanggaan laki-laki" (1 Korintus 11:5-6) ${ }^{17}$

Dalam agama Islam, hukum menutup aurat adalah wajib bagi laki-laki maupun perempuan yang telah memasuki usia 'aqilbalig. Batasan aurat ditentukan dengan membagi kedalam dua bagian, yakni aurat laki-laki, yaitu antara pusar hingga lutut, dan aurat perempuan, yaitu seluruh tubuh (kecuali wajah dan telapak tangan atau kedua mata saja). Namun, beberapa ulama juga berbeda interpretasi mengenai batasan aurat perempuan ini tergantung pada konteks dan situasi. Bahkan beberapa Negara ada yang terkesan memaksakan secara ketat, sedangkan sebagian lainnya seolah-olah mendiskriminasi karena aturan dan larangan penguasa. ${ }^{18}$

Menutup aurat dalam Islam diimplementasikan dengan berbagai macam bentuk penutup aurat dalam Al-Qur'an dan Hadis. Dalam hal ini, penulis akan membatasi dalil/nas hanya pada lingkup ketentuan atau perintah menutup aurat sebagai berikut.

\section{a. Khumur (خمر)}

Dari sisi kaidah linguistik Arab, kata khimär merupakan bentuk tunggal dari kata

17 Alkitab, Cet. VIII (Jakarta: Lembaga Alkitab Indonesia, 2009), 260.

18 Fathonah K. Daud, "Jilbab, Hijau dan Aurat Perempuan : Antara Tafsir Klasik, Tafsir Kontemporer dan Pandangan Muslim Feminis", dalam AL-HIKMAH Jurnal Studi Keislaman, Vol. 3, No. 1, Maret 2013, 2 dan 7. Lihat juga, Nasaruddin Umar, "Fenomenologi Jilbab", dalam http://WwW.kompas.com/kompascetak/0211/25/dikbud/feno36.htm, diakses pada tanggal 4 Desember 2015. khumur, yang berarti menutupi sesuatu. ${ }^{19}$ Penggunaan kata khumur ini hanya terdapat satu ayat saja di dalam Al-Qur'an, yaitu QS. An-Nūr [24]: 31. Sedangkan menurut istilah, sebagaimana diungkapkan Abdurrahman bin Ishaq mengutip penafsiran Ibnu Katsir bahwa, Khimär adalah sesuatu yang dijadikan sebagai penutup kepala yang menjulur ke dadanya sehingga dada dan lehernya. Ayat ini turun berdasarkan konteks sosial perempuan Arab Jahiliyyah masa itu yang cara memakai penutup kepalanya cenderung hanya sekedar meletakkan kerudung diatas kepala kemudian menjulurkannya dari sisi kanan ke bahu kiri sama seperti sorban bagi laki-laki. ${ }^{20}$ Oleh sebab itu, untuk membedakan perempuan muslim dengan perempuan Jahiliyyah, Allah SWT. memerintahkan mereka untuk menutupi aurat untuk menjaga kehormatan mereka. ${ }^{21}$

\section{b. Jalabib (جلابيب)}

Menurut bahasa, kata jalabib merupakan bentuk jamak dari kata jilbab yang berarti mendatangkan sesuatu (jalaba-yajlubujalban). ${ }^{22}$ Sedangkan menurut istilah, definisi dan pemahaman tentang jilbab ini berbedabeda setiap negara. Negara-negara Timur Tengah pada umumnya memahami bahwa jilbab adalah pakaian longgar (baju kurung/jubah) termasuk jilbab yang menutupi seluruh badan. ${ }^{23}$ Lain di Indonesia, jilbab

19 Al-Ragib al-Asfihani, Mu'jam Mufradat li alFāz Al-Qur'an (Beirut: Dar al-Fikr, t.th.), 160. Lihat pula, Rohi Baalbaki, Al-Mawrid..., 523.

20 Ibnu Hajar al-Asqalani, Fatḥ al-Bāri Syarh Sahịh al-Bukhāri, terj. Amiruddin (Jakarta: Pustaka Azzam, 2008), 482.

${ }^{21}$ Al-Qurthubi, Al-Jami' li Aḥkām al-Qur'ān, Juz XII (Beirut: Dar al-Kutub al-'Ilmiyyah, 1993), 201.

22 Muhammad bin Ahmad al-Azhari, Mu'jam Tahzīib al-Lugah, Juz IV (Beirut: Dar al-Ma'rifah, 2001), 14. Di tempat lain, kata Jilbāb bermakna menghimpun dan membawa. Lihat Rohi Baalbaki, AlMawrid..., 426.

23 Hal ini dapat terlihat dari penafsiran para ulama, seperti Zamakhsyari dalam kitab "AlKasysyaf”, al-Qurthubi dalam "Al-Jami” li Ahkām alQur'ān”, Imam Syaukani dalam "Fath al-Qadir", dan lain-lain. 
dipahami sebagai penutup kepala yang hanya menutupi rambut saja.

Dalam sebuah Hadis dikisahkan seorang perempuan menemui Rasulullah SAW. Dan bertanya apakah seorang perempuan tidak mengikuti shalat Ied karena tidak memiliki jilbab, maka Rasulullah mengisyaratkan agar kawannya dapat meminjamkan jilbab untuknya. $^{24}$

Kata ini terdapat dalam QS. Al-Ahzab [33]: 59 yang merupakan kiasan (majaz) dari menutup wajah dengan jilbab, sebagaimana dikatakan oleh al-Zamakhsyari dalam "AlKasysyaf" dan Faid dalam "Al-Safi". Muhammad Ali al-Sabuni menakwilkan kalimat ini dengan pernyataan untuk memakai pakaian jilbab yang longgar dan luas yang menutupi keindahan tubuh dan perhiasannya seperti baju kurung. ${ }^{25}$

\section{c. Hijab (حجاب)}

Kata ini salah satunya terdapat dalam QS. Al-Ahzāb [33]: 53. Ibnu Katsir menafsirkan bahwa yang dimaksud hijab disini adalah tata cara melakukan interaksi dengan isteri-isteri Nabi SAW. Ketika ada keperluan. Tidak diperbolehkan untuk memandang secara menyeluruh dan harus ada penghalang berupa tirai yang membatasi antara keduanya. ${ }^{26}$ Ayat diatas menjadi ketetapan yang jelas mengenai kewajiban berhijab perempuan kepada lakilaki. Secara khusus ayat di atas diperuntukkan kepada isteri-isteri Nabi. Meski demikian, ayat ini juga dapat berlaku umum untuk setiap perempuan muslim, mengingat berhijab dapat menjaga kesucian hati laki-laki maupun perempuan dan menjauhkan diri dari perbuatan keji dan timbulnya fitnah. ${ }^{27}$

${ }^{24}$ Lihat Bukhari, Sahịh Bukhari, Kitab Haid, Bab Wanita haid menghadiri shalat dua Hari Raya dan mendegarkan khutbah dan do'a bagi Kaum Muslimin namun mereka dijauhkan dari tempat shalat, No. Hadis t 313 .

${ }^{25}$ Muhammad Ali as-Shabuni, Rawā'i al-Bayān, juz II (Beirut: Dar al-Fikr, t.th.), 58-59.

${ }^{26}$ Abdullah bin Muhammad bin Abdurrahman bin Ishaq Alu Syaikh (pentahqiq), Lubāb al-Tafsir..., 320.

${ }^{27}$ Abdul Aziz bin Abdullah, "Persoalan Hijāb dan Cadar" dalam Abdul Aziz bin Baz dan Muhammad ibn
Membatasi pergaulan yang dimaksud adalah mengurangi interaksi berlebih-lebihan dengan lawan jenis, tanpa kepentingan dan tujuan yang jelas. Sebab, bisa jadi laki-laki dan perempuan dapat melakukan perbuatan maksiat karena godaan setan jika berduaan tanpa disertai mahramnya. Hal ini dapat disebut khalwat dan diharamkan oleh para ulama.

\section{Tradisi Pemakaian "Rimpu" Masyarakat Bima}

\section{a. Kesultanan Bima dalam Sejarah}

Seperti halnya daerah-daerah lain di Indonesia, Bima mempunyai catatan sejarah yang tidak ternilai, terhitung sejak berdiri tahun $1050 \mathrm{H} / 1631 \mathrm{M}^{28}$, sehingga peranannya dalam pembentukan sejarah Nusantara sangat penting. Evolusi bentuk politik dan pemerintahan telah berkembang dan berlangsung sejak berabad-abad silam, mulai dari masa prasejarah (Naka) hingga sekarang ini. $^{29}$

Shalih al-Utsaimin, Hukum Hijab dan Cadar" (Solo: Pustaka Mantiq, 1995), 60.

${ }^{28}$ Penentuan tahun kelahiran daerah Bima ini terhitung sejak masa awal masa dimulainya Kesultanan Bima, yakni pengangkatan Sultan Abdul Kahir (La Ka'i) sebagai sultan pertama yang memerintah di Kesultanan Bima pada tahun 1050 H/1631 M. Meskipun penentuan ini menimbulkan pertentangan dari beberapa kalangan yang menilai bahwa kelahiran daerah Bima (Kabupaten/Kota Bima) bersamaan dengan dibekukannya sistem pemerintahan Kesultanan atau Kerajaan di Seluruh Indonesia oleh Presiden RI pertama Ir. Soekarno pada tahun 1951. Lihat, Rangga Babuju "Kekeliruan menyatakan HUT Kab. Bima" dalam

http://www.kompasiana.com/ranggababuju/kekeliruanmenyatakan-hut-kab-

bima 552b8ab16ea834a5098b4596, diakses pada tanggal 05 November 2015.

${ }^{29}$ Menurut M. Hilir Ismail, perkembangan politik dan pemerintahan Daerah Bima terbagi menjadi 7 (tujuh) bagian, yaitu Masa Naka, Masa Ncuhi, Masa Kerajaan, Masa Kesultanan, Masa Swapraja, Masa Swatantra, dan Masa Kabupaten Dati II. M. Hilir Ismail, Peran Kesultanan Bima dalam Perjalanan 
Tidak ada data pasti mengenai kapan terbentuknya wilayah Bima, namun menurut data sejarah, sejak zaman Naka (masa "tertua" sejarah Bima), pertumbuhan dan perkembangan peradaban Bima ditandai dengan kejayaan sektor industri geografis, yakni pemanfaatan daerah-daerah subur di delta-delta sungai dan dataran rendah untuk hasil alamnya. Sehingga setelah masuk abad XI pun pelabuhan Bima menjadi pusat perniagaan Nusantara pada saat itu. ${ }^{30}$

Persoalan keagamaan pada masa-masa awal, masyarakat Bima masih menganut sistem kepercayaan Animisme ${ }^{31}$ yang disebut Makamba-Makimbi atau Parafu. Hal ini dibuktikan dengan temuan Arkeologi yang ditemukan di pegunungan Doro Nocu, Sape, Bima dan di Tolo Donggo, Bima berupa tempat pemujaan dan kuburan prasejarah yang terdiri atas batu-batuan. ${ }^{32}$ Kemudian agama berganti pengaruh Hindu $^{33}$ pada masa kepemerintahan Raja Erlangga dari Kerajaan Medang berkuasa di Jawa. Baru pada tahun $1618 \mathrm{M}$, Islam masuk dan memberi dampak besar pada struktur pemerintahan menjadi Kesultanan yang berlandaskan syari'at Islam.

Menurut Abdul Ghani Abdullah, perlu adanya kerangka berpikir bagi upaya memahami proses perkembangan Islam di Bima, yaitu :

Pertama, pengetahuan orang Bima mengenai telah adanya orang-orang luar Bima

Sejarah Nusantara (Mataram: Penerbit Lengge, 2004), 22.

${ }^{30}$ M. Hilir Ismail, Peran Kesultanan Bima..., 4.

${ }^{31}$ A·ni·mis'me $n$ kepercayaan kepada roh yang mendiami semua benda (pohon, batu, sungai, gunung, dsb). CD Kamus Besar Bahasa Indonesia Offline 1.2 (t.t: Pusat Bahasa Diknas, t.th).

32 M. Fachrir Rahman, Islam di Bima : Kajian Historis tentang Proses Islamisasi dan Perkembangannya sampai Masa Kesultanan (Yogyakarta: Genta Press, 2008), 86.

33 Terdapat beberapa situs yang membuktikan eksistensi pengaruh Hindu di wilayah Bima yang masih dapat ditemukan di sekitar wilayah Bima, diantaranya situs "Wadu Pa'a" (kuil), "Wadu tunti" (batu tulis), "Lingga", dan lain-lain. M. Fachrir Rahman, Islam di Bima..., 90-91. yang menganut agama Islam. Kedua, datang untuk pertama kalinya orang beragama Islam di Bima. Ketiga, adanya orang Bima pertama yang memeluk agama Islam. Keempat, terjadinya pengislaman orang-orang Bima setelah terjadi pengislaman menurut tahap ketiga. $^{34}$

Seperti dilansir dalam salinan kitab $B O^{\prime}$ Sangaji Kai yang ditulis pada tanggal 18 Rabi'ul Akhir 1270 H, berbunyi :

"Hijratun Nabi SAW. Sanad Seribu dua puluh delapan, sebelas hari bulan Jumadil Awal telah datang di Labuhan Sape Saudara Daeng Mangali di Bugis Sape dengan orang Luwu, Tallo, dan Bone untuk berdagang. Kemudian pada malam hari datang menghadap Ruma Bumi Jara yang memegang Sape untuk menyampaikan sebuah Ci'lo dan kain bugis, dan sepucuk surat sepupu Ruma Bumi Jara di Bone bernama Daeng Malaba. Adapun saudaranya itu menghabarkan bahwa orang-orang itu berdagang cilo dan kain dan keris serta membawa agama Islam. Kerajaan Gowa dan Tallo dan Luwu dan Bone sudah masuk Islam dan Daeng Malaba dan keluarganya semua sudah Islam. Dimintanya Bumi Jara agar jadi Islam dan membawa orang-orang itu menghadap Ruma Bicara Ama Lima Dai, sebab ada persembahan untuk Ruma Bicara. Pada saat itu, Ruma Bicara telah wafat dan tidak diketahui oleh orang-orang Tallo dan Bone. Orang-orang itu dibawa oleh Bumi Jara kepada adik Ruma Bicara bernama Rato Waro Bewi dan anak Ruma Bicara La Mbila. Tiada di rumah, karena sudah pergi ke Dusun Teke menjaga Ruma Ta Ma Bata Wadu (La Ka'i), disuruh oleh Rato Waro Bewi, karena Ruma Ta Ma Bata Wadu dikejar-kejar oleh Mantau Asi Peka hendak dibunuh dan seterusnya." 35

34 Syarifuddin Jurdi, Islamisasi dan Penataan Ulang Identitas Masyarakat Bima : Dinamika Politik "Dana Mbojo" 2000-2010. Makalah orasi ilmiah Wisuda Sarjana STAIM Bima, 2010, 9.

35 Henri Chambert-Loir dan Siti Maryam R. Salahuddin (penyunting), Bo' Sangaji Kai : Catatan Kerajaan Bima, Edisi II (Jakarta: Yayasan Pustaka Obor Indonesia, 2012), 225. 
Dari penjelasan $B o^{\prime}$ di atas, dapat diambil kesimpulan bahwa Islam masuk lewat jalur perdagangan damai oleh pedagang dari Gowa, Tallo, Luwu dan Bone pada sekitar tahun 1618 $\mathrm{M}$, yang kemudian berhasil mengislamkan La Ka'i (kemudian merubah namanya menjadi Abdul Kahir) sebagai sultan pertama.

Akan tetapi, dari sumber lain menyebutkan bahwa sebenarnya Islam telah masuk dan menyebar terlebih dahulu oleh para pendakwah dari Kerajaan Islam Demak yang dipimpin oleh Sunan Prapen (putra dari Sunan Giri) antara tahun 1540-1550 $\mathrm{H}^{36}$ Namun, hingga kedatangan pedagang dari Gowa, Tallo, Luwu dan Bone nampaknya penyebarannya tidak berlangsung lama dan vakum pada pertengahan abad ke-16. Dengan demikian penyebaran dan perkembangan Islam di Bima tidak lepas juga dari pengaruh dari Kerajaan Islam Demak yang kemudian ditransmisikan kembali oleh Kerajaan Malaka.

Dengan demikian, maka secara resmi berdiri Kerajaan Bima berlandaskan syari'at Islam (Kesultanan Bima) pada tanggal 15 Rabi'ul Awal 1050 H/1631 M dengan Sultan Abdul Kahir Ruma Ta Ma Bata Wadu sebagai sultan pertama. Selain memakai hukum agama, Kesultanan Bima pun tidak meninggalkan sistem hukum Hadat Mbojo (adat Bima) yang sesuai dengan etika dan moral masyarakat Bima. Setelah transformasi sistem politik-pemerintahan dari Kerajaan menjadi Kesultanan, maka secara otomatis seluruh pemberlakuan hukum dan adat juga bernafaskan syari'at Islam. Raja/sultan yang telah mengislamkan diri juga membawa pengaruh islamisasi besar-besaran yang dilakukan oleh rakyatnya, sebagai bukti kepatuhan dan ketaatan terhadap pemimpinnya.

\section{Definisi dan Jenis "Rimpu"}

Suku Mbojo sebagai salah satu suku yang hingga kini masih eksis di Indonesia dikenal sebagai suku yang kuat dengan asas keislamannya. Hal ini terlihat dari penanaman nilai-nilai estetik keislaman dalam beberapa

36 A. Salim Harahap, Sejarah Penyiaran Islam (Jakarta: t.tp, t.th), 55.
Adat Dana Mbojo (adat Bima). Pada zaman dahulu, masyarakat Bima sangat menjunjung tinggi nilai keislaman, dikarenakan sifat maja (malu) dan dahu (takut) terhadap sanksi agama dan sosial sangat melekat ${ }^{37}$.

Rimpu adalah pakaian tradisional seharihari masyarakat Mbojo (terutama perempuan) untuk menutup aurat. Menurut Syaukani, Tokoh masyarakat dan Budayawan Bima, secara bahasa kata "Rimpu" dalam bahasa Bima diambil dari gabungan dua suku kata, yaitu $R i$ yang bermakna 'kembali' dan $M p u$ yang berarti 'menutup'. ${ }^{38}$ Sedangkan menurut istilah, Rimpu adalah pakaian yang menutupi anggota tubuh perempuan yang disebut aurat dengan menggunakan kain sarung khas (Tembe Nggoli). ${ }^{39}$ Penggunaan sarung sebagai Rimpu ini karena Tembe Nggoli pada saat itu sangat populer sebagai pakaian yang digunakan masyarakat Mbojo sehari-hari, selain karena faktor kepraktisan.

Tradisi pemakaian Rimpu ini telah ada sejak masa nenek moyang masyarakat suku Mbojo dan kemudian pihak Kesultanan Bima membuat maklumat/himbauan agar pemakaian Rimpu diwajibkan bagi semua perempuan muslim Mbojo $^{40}$ yang telah 'aqil-balig. ${ }^{41}$

${ }^{37}$ M. Hilir Ismail, Menggali Pusaka Terpendam : Butir-Butir Mutiara Budaya "Mbojo" (Bima: t.tp, 2001), 6.

${ }^{38}$ Hanafi, "Pergeseran Budaya Rimpu (Cadar ala Mbojo) dan Pengaruhnya terhadap Pendidikan Akhlak Remaja". Skripsi Fakultas Tarbiyah, Institut Perguruan Tinggi Ilmu al-Qur'ān (IPTIQ) Jakarta, 2008, 10.

${ }^{39}$ MR Pahlevi Putra N.I. Singke, Salungka Pa'a : Ragam Hias Kain Tradisional Masyarakat Dompu Kultur Kain Tenun Songket Dompu (Lombok: CV Rossamari Sentausa, 2011), 11.

${ }^{40}$ Suku Mbojo dalam artian sejarah adalah Tanah Bima yang pada masa dahulu masih bergabung dengan Tanah Dompu, sehingga kebudayaan maupun adat keduanya menjadi sama (hingga saat ini) karena serumpun/se-suku, meskipun secara politikpemerintahan kemudian Dompu membangun Kesultanan sendiri pada September 1545 dengan Sultan Samsudin sebagai Sultan Dompu pertama. Keterangan lebih lanjut, lihat Moh. Kisman Pangeran, Dari Kontrak Panjang Hingga Musnahnya Istana dari 
Meskipun maklumat tersebut tidak tertulis (bersifat lisan), namun maklumat Sultan secara langsung tetap berlaku untuk seluruh rakyat. ${ }^{42}$

Perihal asal-mula (sejarah) tradisi/budaya Rimpu ini, setidaknya ada dua argumen yang muncul:

Pertama, Pendapat yang dikemukakan oleh Sejarawan Bima, M. Hilir Ismail bahwa budaya Rimpu ini muncul sekitar abad XVII, berkenaan dengan diproklamirkannya Kerajaan Islam di Tanah Bima yang berlandaskan syari'at Islam. Dari pendapat ini didapatkan suatu poin bahwa budaya Rimpu adalah hasil prakarsa atau ide-ide kesultanan dan rakyat Bima ketika Islam masuk dan menyentuh tanah Bima, sebagai implementasi dari perintah Allah dalam Al-Qur'an tentang kewajiban perempuan untuk menutup auratnya. Disamping itu, budaya Rimpu juga sebagai wujud menciptakan generasi yang ideal dan ber-akhlaq al-Karimah serta memperkuat hubungan kekerabatan, budaya daerah, dan lain sebagainya. ${ }^{43}$

Kedua, adalah kelompok dengan asumsi bahwa budaya Rimpu sebenarnya telah ada dipakai oleh nenek moyang dahulu sebelum Islam masuk di Tanah Bima. ${ }^{44}$ Pada zaman dahulu, Rimpu digunakan untuk menghalangi kulit agar tidak terpapar panas matahari. ${ }^{45}$ Selain itu, pemakaian Rimpu pada zaman itu

Rakyat : Kisah Sultan Muhammad Menentang Korupsi (Bogor: Morinawa, 2013), hlm 14.

${ }^{41}$ Wawancara dengan ibu Ruhana dan ibu Siti Aminah, Tokoh Perempuan Ngali, di Desa Ngali, tanggal 23 Oktober 2015.

${ }^{42}$ Menurut Daud Ali, Hukum Islam pada saat itu tidak tertulis dalam bentuk perundang-undangan kepemerintahan, melainkan berlaku hukum fiqih hasil ijtihad para ulama yang dilakukan secara patuh oleh masyarakat Islam karena kesadaran dan keyakinan mereka bahwa hukum Islam adalah hukum yang benar. Lihat, Muhammad Daud Ali, Hukum Islam..., 211.

43 M. Hilir Ismail, Menggali Pusaka Terpendam..., hal. 7.

${ }^{44}$ Hanafi, "Pergeseran Budaya Rimpu"..., 25.

${ }^{45}$ Diskusi grup "Komunitas Sanggar Seni dan Tradisi Rimpu Jogja" oleh Wahidin Putra di Blandongan Café, Gowok, Yogyakarta, tanggal 2 Maret 2015. didasarkan kepada kepercayaan nenek moyang (makamba-makimbi) yang sangat menjunjung tinggi derajat dan kedudukan wanita.

Pada umumnya, jenis Rimpu terbagi menjadi 2 (dua) macam, yaitu:

a. Rimpu Mpida, yaitu pakaian yang menutup bagian tubuh/aurat perempuan remaja/gadis (kecuali kedua mata).

b. Rimpu Colo/Tada, yakni pakaian yang menutup aurat perempuan yang sudah berkeluarga (menikah/janda/lansia) dengan seluruh bagian tubuh tertutup kecuali wajah. ${ }^{46}$

Adapun bahan yang digunakan untuk Rimpu adalah dua buah sarung (Tembe Nggoli). Sarung pertama berfungsi seperti rok yang menutupi bagian bawah tubuh perempuan, dan sarung kedua sebagai penutup kepala dengan cara melilitkannya tanpa alat penyangga/pengait apapun (peniti, jarum, bros, dsb.). Sarung khas ini bagi masyarakat Bima merupakan komoditi andalan untuk memperkenalkan kekayaan khazanah budaya dan etnis suku Mbojo lewat corak sarung. Umumnya, motif/corak sarung di setiap desa di Kabupaten/Kota Bima mempunyai motif/corak sarung masing-masing, contohnya motif Tembe Renda, Tembe Ngali, dll. ${ }^{47}$

\section{Manfaat dan Nilai "Rimpu"}

Dilihat dari berbagai sisi, menurut Hanafi, esensi dan manfaat Rimpu ini adalah sama dengan tren jilbab yang saat ini sedang marak, diantaranya :

a. Kedua pakaian tersebut sama-sama menutup aurat wanita dari kapala sampai ujung kaki.

b. Kedua pakaian tersebut sama-sama bersifat longgar dan panjang atau tidak membungkus badan.

${ }^{46}$ Manggaukang Raba dan Mars Ansory Wijaya, Dompu : Dulu, Kini dan Esok (Mataram: UD Bugenvil, 2002), 64.

${ }^{47}$ Wawancara dengan ibu Hj. Nurawah, pemakai Rimpu, di Desa Ngali, tanggal 25 Oktober 2015. 
c. Antara busana Rimpu dan busana yang dianjurkan Islam sama-sama memakai kain yang tebal dan panjang. ${ }^{48}$

Ketiga indikator diatas didasarkan pada kriteria dan prinsip menutup aurat berdasarkan perintah menutup aurat dan konsep pakaian penutup aurat menurut Al-Qur'an dan Hadis. Sehingga Rimpu yang dipakai oleh perempuan "Mbojo" mempunyai manfaat sebagai berikut

1) Berfungsi sebagai penutup aurat dan mempercantik penampilan

2) Menghalangi dari sengatan panas matahari dan cuaca dingin

3) Menjaga kemuliaan perempuan dan menghindari gangguan laki-laki 'jahil'

Akan tetapi, pada perkembangannya, fungsi dan pemakaian Rimpu menjadi sedikit 'bergeser'. Hal ini dikarenakan berbagai faktor, seperti masuknya kebudayaan asing, perkembangan fashion yang lebih up-to-date, dan lain-lain. Ketika pada masa Kesultanan Bima berjaya, Rimpu dikenakan oleh seluruh perempuan Mbojo (kecuali keluarga Bangsawan) sehari-hari. Meskipun pada saat ini, Rimpu masih tetap dipergunakan oleh masyarakat Mbojo, namun jumlahnya semakin berkurang, sehubungan dengan munculnya tren jilbab, hijab, dll. yang lebih praktis dan fashionable. Namun, seluruh elemen masyarakat Bima masih melestarikan tradisi Rimpu di kehidupan sehari-hari dan pada acara-acara tertentu, seperti pawai kebudayaan, HUT Kota, dll.

\section{Resepsi Al-Qur'an-Hadis dalam Tradisi Pemakaian "Rimpu"}

Sebagai sebuah disiplin teori sosiologi, "Sosiologi Pengetahuan" termasuk teori yang sangat baru dikembangkan. Layaknya sebuah teori, ia digunakan untuk menganalisis secara historis-sosiologis hubungan antara pengetahuan dan kehidupan sekitar. Sehingga teori ini bertujuan untuk menemukan tahapan

\footnotetext{
${ }^{48}$ Hanafi, “Pergeseran Budaya Rimpu”..., 31.
}

dan substansi keterkaitan antara pikiran dan tindakan secara operasional. $^{49}$

Berdasarkan poin deskripsi diatas, penulis akan menganalisis hubungan antara makna dan praktik implementasi ayat Al-Qur'an dan Hadis menutup aurat dalam tradisi pemakaian "Rimpu" di Masyarakat desa Ngali, kec. Belo, kab. Bima. Makna tersebut dianalisis dari perspektif sosio-historis dan personal pemakai Rimpu, Lebe/ulama, dan budayawan Bima itu sendiri dengan menggunakan klasifikasi makna dalam teori Sociology of Knowledge oleh Karl Mannheim, yakni :

a. Makna obyektif, adalah makna yang ditentukan oleh konteks sosial dimana tindakan itu berlangsung, dimana tradisi pemakaian Rimpu ini memuat prinsip dan nilai etika berbusana sesuai syari'at Islam yang tercermin dalam cara pemakaiannya. Rimpu dalam hal ini harus sesuai dengan kriteria busana Islami, yakni:

1) Menutup aurat

2) Membuat nyaman jika dipakai, sehingga melindungi dan menjaga kemuliaan dan martabat perempuan

3) Tidak tipis dan tidak memperlihatkan lekuk tubuh. ${ }^{50}$

Adapun tata cara pemakaian Rimpu dapat dijelaskan sebagai berikut:

- Sebelumnya pakaian biasa telah dipakai terlebih dahulu (baju, celana atau rok) sebelum memakai Rimpu

- Selembar sarung dipakai sebagaimana memakai rok dan eratkan di bagian pinggang. Dalam bahasa Bima, istilah memakai sarung ini dinamakan katente tembe

- Kemudian sarung lainnya dipakaikan ke kepala, lalu dililitkan ke arah kiri atas kepala (ubun-ubun), dan diputar kembali

49 Karl Mannheim, Ideology and Utopia : An Introduction to the Sociology of Knowledge (London: Routledge \& Kegan Paul LTD, 1954), 237.

50 Berdasarkan Wawancara dengan ibu Ruhana (Tokoh Perempuan Desa Ngali), ibu Siti Aminah (Tokoh Perempuan Desa Ngali) dan ibu Hj. Siti Maryam (Pemakai Rimpu), di tempat dan waktu yang berbeda. 
seperti membuat surban kepala. Cara pemakaian ini untuk Rimpu Tada bagi perempuan yang telah menikah, janda atau lansia. Sedangkan bagi gadis, wajah harus ditutup terlebih dahulu (kecuali kedua mata) dengan melingkarkan kain sarung kearah kiri wajah, lalu dilingkarkan ke atas kepala. Posisi sarung harus dikait agar kuat dan menutupi seluruh kepala, sehingga rambut tidak akan terlihat. $^{51}$

b. Makna ekspresif, adalah makna yang ditunjukan oleh pelaku tindakan (motif). Oleh sebab itu, penulis membaginya dalam tiga kategori, yaitu makna dari pemakai Rimpu, Lebe/ulama, dan budayawan. Menurut $\mathrm{Hj}$. Salmah (68 tahun, pemakai Rimpu), motif pemakaian Rimpu perempuan Mbojo adalah karena sebagai seorang perempuan Muslim, menutup aurat merupakan sebuah kewajiban dan perintah Allah dalam AlQur'an:

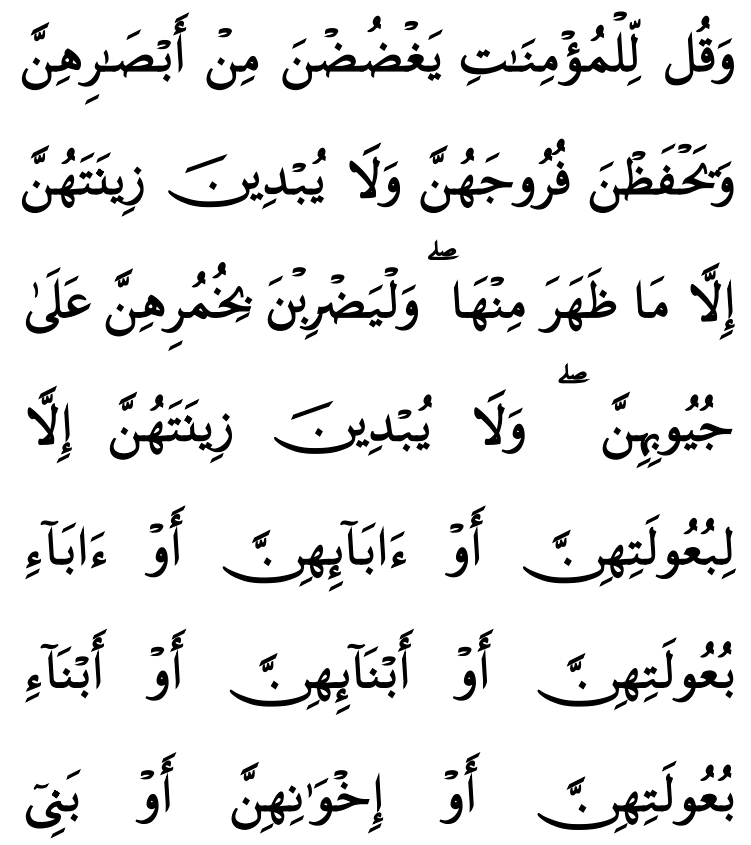

${ }^{51}$ Sebelum memakai Rimpu, ada beberapa syarat yang harus diperhatikan, yaitu pemakai Rimpu adalah seorang perempuan; Usia pemakai Rimpu sudah mencukupi atau telah aqil-baligh; serta, Tembe Nggoli, yakni sarung khas produksi lokal masyarakat Bima yang mempunyai motif/corak yang beragam tergantung wilayahnya.

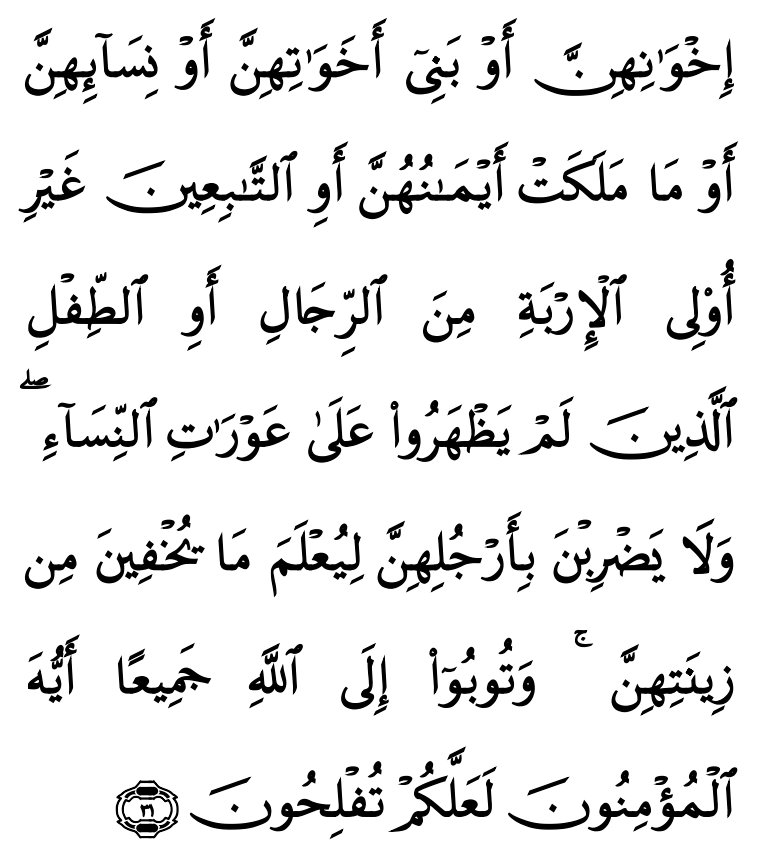

"Katakanlah kepada wanita yang beriman: "Hendaklah mereka menahan pandangannya, dan kemaluannya, dan janganlah mereka Menampakkan perhiasannya, kecuali yang (biasa) nampak dari padanya. dan hendaklah mereka menutupkan kain kudung kedadanya, dan janganlah Menampakkan perhiasannya kecuali kepada suami mereka, atau ayah mereka, atau ayah suami mereka, atau putera-putera mereka, atau putera-putera suami mereka, atau saudara-saudara laki-laki mereka, atau putera-putera saudara lelaki mereka, atau putera-putera saudara perempuan mereka, atau wanitawanita Islam, atau budak- budak yang mereka miliki, atau pelayan-pelayan lakilaki yang tidak mempunyai keinginan (terhadap wanita) atau anak-anak yang belum mengerti tentang aurat wanita. dan janganlah mereka memukulkan kakinyua agar diketahui perhiasan yang mereka sembunyikan. dan bertaubatlah kamu sekalian kepada Allah, Hai orang-orang yang beriman supaya kamu beruntung. (QS. An-Nuur [24]: 31) 


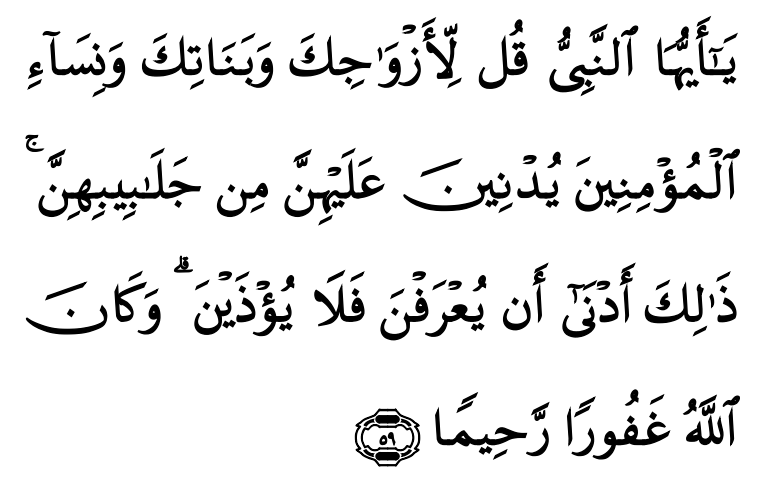

"Hai Nabi, Katakanlah kepada isteriisterimu, anak-anak perempuanmu dan isteri-isteri orang mukmin: "Hendaklah mereka mengulurkan jilbabnya ke seluruh tubuh mereka". yang demikian itu supaya mereka lebih mudah untuk dikenal, karena itu mereka tidak di ganggu. dan Allah adalah Maha Pengampun lagi Maha Penyayang." (QS. Al-Ahzab [33]: 59).

Lain lagi bagi Ruhana (tokoh perempuan desa Ngali) yang mengungkapkan bahwa Rimpu dapat merepresentasikan contoh pakaian Islami yang ideal karena bahannya tebal, longgar dan tidak membentuk badan. ${ }^{52}$ Jika melirik gaya berpakaian wanita saat ini yang meskipun terbilang menutup aurat, namun masih terlihat tipis dan membentuk badan. Sehingga esensi dan nilai moral dari menutup aurat menjadi terkikis hanya karena mengikuti tren fashion yang sedang 'booming' semata. Dalam sebuah hadis, Rasulullah SAW. menegaskan:

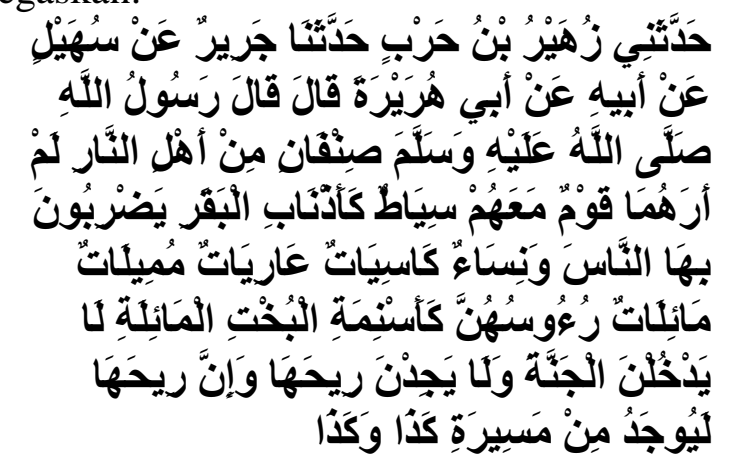

"Telah menceritakan kepadaku Zuhair

bin Harb; Telah menceritakan kepada

52 Wawancara dengan ibu Ruhana, Tokoh Perempuan Desa Ngali, di kediamannya di Desa Ngali, tanggal 23 Oktober 2015. kami Jarir dari Suhail dari Bapaknya dari Abu Hurairah dia berkata; Rasulullah SAW.bersabda: "Ada dua golongan penduduk neraka yang keduanya belum pernah aku lihat. (1) Kaum yang memiliki cambuk seperti ekor sapi, yang dipergunakannya untuk memukul orang. (2) Wanita-wanita berpakaian, tetapi sama juga dengan bertelanjang (karena pakaiannya terlalu minim, terlalu tipis atau tembus pandang, terlalu ketat, atau pakaian yang merangsang pria karena sebagian auratnya terbuka), berjalan dengan berlenggok-lenggok, mudah dirayu atau suka merayu, rambut mereka (disasak) bagaikan punuk unta. Wanita-wanita tersebut tidak dapat masuk surga, bahkan tidak dapat mencium bau surga. Padahal bau surga itu dapat tercium dari begini dan begini. " ${ }^{53}$

Merupakan salah satu upaya iblis untuk menghasut dan memperalat perempuan agar menampakkan auratnya, sehingga terjadi keburukan dan kemaksiatan. Hal ini mengingatkan tentang kisah pengusiran Adam as. dan Hawa dari surga karena memperturutkan hawa nafsu dan godaan Iblis. Sebagaimana dalam firman Allah:
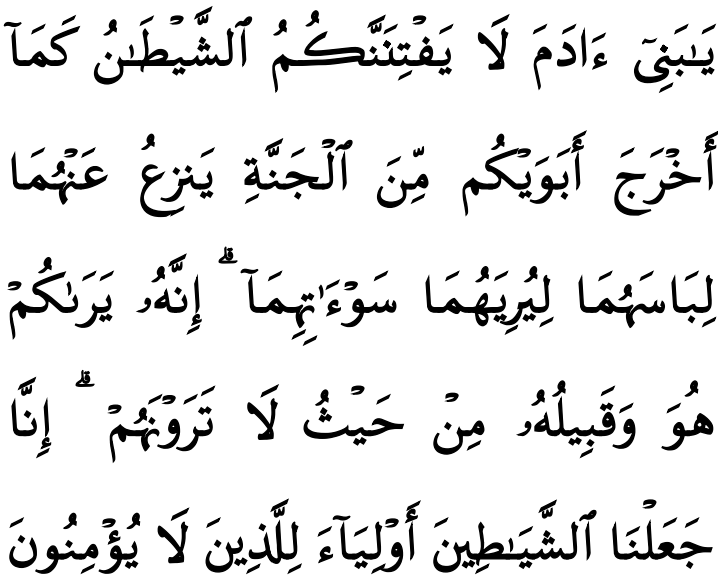

53 Muslim, Shahih Muslim, Kitab Pakaian dan perhiasan, Bab Wanita berpakaian tetapi telanjang, No. Hadist 3971. CD Ensiklopedi Hadits Kitab 9 Imam (t.t: Lidwa Pustaka i-Software, t.th.). 
"Hai anak Adam, janganlah sekali-kali kamu dapat ditipu oleh syaitan sebagaimana ia telah mengeluarkan kedua ibu bapamu dari surga, ia menanggalkan dari keduanya pakaiannya untuk memperlihatkan kepada keduanya 'auratnya. Sesungguhnya ia dan pengikutpengikutnya melihat kamu dan suatu tempat yang kamu tidak bisa melihat mereka. Sesungguhnya Kami telah menjadikan syaitan-syaitan itu pemimpinpemimpim bagi orang-orang yang tidak beriman." (QS. Al-A'rāf [7] : 27)

Sementara menurut H. M. Nur, seorang Lebe/ulama desa Ngali menjelaskan alasan pentingnya budaya Rimpu ini dilestarikan, diantaranya:

- Faktor karakter etnis, karena Rimpu merupakan tradisi yang hanya dimiliki oleh suku Mbojo saja

- Motif keagamaan. Pemahaman agama spesifik yang dianut oleh masyarakat Mbojo, yakni Ahlus Sunnah wal Jama'ah menjadikan tradisi Rimpu fanatik di masyarakat sebagai praktik implementasi dari anjuran menutup aurat berdasarkan dalil Al-Qur'an dan Hadis.

- Adanya kontrol sosial sehingga apabila perempuan tidak menutup aurat (berRimpu), maka akan menjadi pembicaraan dan dikuncilkan oleh masyarakat sekitar. Pada masa kesultanan Bima, yang bertugas mengontrol tradisi Islam di masyakat Bima adalah ulama dan anggota Badan Hukum Syara' Tanah Bima, namun setelah runtuhnya kesultanan, secara tidak langsung masyarakat luas juga bertanggung jawab mengawasi praktik keberagamaan tersebut di tanah Bima. ${ }^{54}$

Selain itu, budayawan Bima turut memberikan argumentasinya dalam perspektif sejarah. Menurut Ruma Mari Dr. Hj. Siti Maryam Salahuddin, yang merupakan putri Sultan Muhammad Salahuddin (1917-1950 M) menceritakan:

${ }^{54}$ Wawancara dengan bpk. Muhammad H.M. Nur, Lebe, di kediamannya di Desa Ngali, tanggal 25 Oktober 2015.
Pada masa pemerintahan Sultan Muhammad Salahuddin, peradaban Islam di Dana Mbojo sangat berkembang dan berjaya. Salah satunya dengan tetap mempertahankan eksistensi Rimpu sebagai salah satu budaya Bima yang khas. Saat itu, Rimpu dipakai oleh rakyat biasa untuk menjalankan aktivitas sehari-hari. Sedangkan di acara formal dalam istana semuanya menggunakan pakaian adat. Permaisuri, putri dan para selir pun tidak menggunakan Rimpu, sebab mereka mempunyai pakaian khusus keturunan raja dan bangsawan. Inilah salah satu usaha pemerintah kesultanan sebagai pendekatan kepada syi'ar keagamaan. Selain sebagai praktik menutup aurat sesuai dengan perintah Al-Qur'an dan Hadis, keberadaan bahan Rimpu, yakni kain sarung (Tembe Nggoli) mudah didapat, karena para perempuan Mbojo saat itu banyak yang pandai menenun. Oleh sebab itu pakaian Rimpu merupakan pakaian rakyat yang sangat ekonomis dan kemudian digalakkan sultan sebagai hasil kerajinan lokal yang bernilai. Meskipun kenyataannya sekarang Rimpu telah bergeser dengan adanya jilbab, hijab, dll, namun masyarakat mbojo di beberapa daerah pedesaan seperti Ngali, Sape, Donggo, bahkan kabupaten Dompu masih 'betah' dengan Rimpu. Ini yang harusnya menjadi perhatian lebih pemerintah atau Bupati maupun Gubernur sekarang agar kebudayaan lokal tetap lestari dan tidak punah." 55

Senada dengan Dr. Hj. Siti Maryam Salahuddin, KH. Ghani Masykur (sesepuh ulama Bima), menggambarkan bagaimana peranan Lebe/ulama Bima sebagai agency yang menyebar di setiap daerah Bima sebagai transmitter dalam mengawasi dan memutuskan hukum yang berjalan di Kesultanan Bima agar tetap berpedoman kepada Al-Qur'an dan Hadis. Termasuk dalam hal sosialisasi kewajibab ber-Rimpu untuk seluruh perempuan Bima. Dampaknya tidak

55 Wawancara dengan ibu Dr. Hj. Siti Maryam Salahuddin (Ruma Mari), Putri Sultan Muhammad Salahuddin, di kediamannya di Karara, Kota Bima, tanggal 1 November 2015. 
hanya dirasakan oleh kaum perempuan. Lakilaki pun merasa senang jika melihat perempuan yang berhijab karena kesan mereka bahwa perempuan itu adalah perempuan baikbaik. Perempuan dapat dinilai saat caranya berhijab maupun ber-Rimpu terlihat bermartabat dan baik akhlaknya. ${ }^{56}$ Sebab, kunci dari baiknya sebuah Negara adalah karena moral dan akhlak perempuannya yang baik. Rasulullah SAW. bersabda:

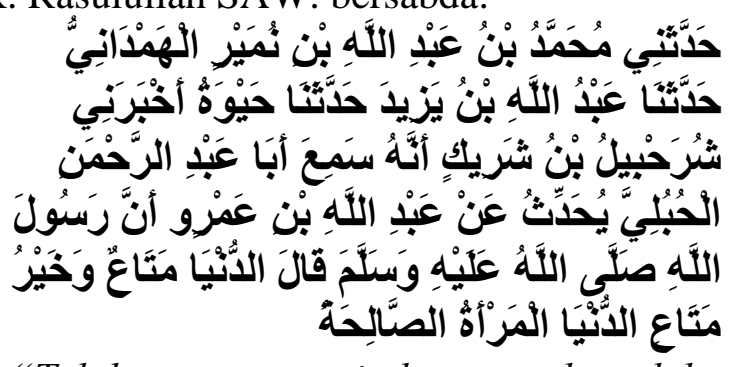

"Telah menceritakan kepadaku Muhammad bin Abdullah bin Numair Al Hamdani telah menceritakan kepada kami Abdullah bin Yazid telah menceritakan kepada kami Haiwah telah mengabarkan kepadaku Syurahbil bin Syarik bahwa dia pernah mendengar Abu Abdurrahman Al Hubuli telah bercerita dari Abdullah bin 'Amru bahwasannya Rasulullah SAW.bersabda: "Dunia adalah perhiasan dan sebaik-baik perhiasan adalah wanita shalihah. ${ }^{157}$

c. Makna dokumenter, yaitu makna yang tesirat atau tersembunyi, sehingga aktor (pelaku tindakan) tidak menyadari sepenuhnya bahwa suatu aspek yang ia lakukan menunjukan kepada kebudayaan menyeluruh. $^{58}$ Dalam hal ini, penulis mencoba menunjukkan bahwa proses implementasi ayat Al-Qur'an dan Hadis

56 Wawancara dengan KH. Ghani Masykur, sesepuh ulama Bima, di kediamannya di Kota Bima, tanggal 28 Oktober 2015.

57 Muslim, Sahịh Muslim, Kitab Menyusui, Bab Sebaik-baik harta dunia adalah wanita yang shalihah, No. Hadis 2668. CD Ensiklopedi Hadis Kitab 9 Imam (t.t: Lidwa Pustaka i-Software, t.th.).

${ }^{58}$ Gregory Baum, Truth Beyond Relativism, terj. Achmad Murtajib (Yogyakarta: PT. Tiara Wacana Yogya, 1999), 15-16.
Menutup Aurat dalam Tradisi Pemakaian Rimpu masyarakat Bima mengarah pada suatu kebudayaan yang kuat doktrin yang dirintis sejak masa Kesultanan Bima melalui para Lebe/ulama yang mempunyai otoritas dan peran besar dalam masyarakat Bima umumnya

Seperti yang telah diketahui, ada beberapa elemen penting yang membentuk budaya dalam suatu masyarakat. Pertama, pemerintahan; Kedua, agen (tokoh) budaya. Dalam hal ini, tradisi Rimpu tidak dapat dilepaskan dari kedua unsur tersebut, yakni dorongan Kesultanan Bima dan peranan ulama/Lebe dalam yang tersebar di seluruh wilayah Bima (sebagiannya menjabat sebagai anggota Badan Hukum Syara' Tanah Bima). Kedua unsur ini saling memperkuat satu sama lain untuk mencapai tujuan dan kepentingan masyarakat umum.

Tradisi Rimpu ini masih tetap terjaga dan dilestarikan hingga saat ini tidak lepas dari peranan Badan Hukum Syara' Tanah Bima yang saat itu berperan mengawasi tradisi ini secara langsung. Apabila tradisi ini disalahgunakan dan tidak sesuai dengan nilainilai syari'at Islam, maka hal ini sepenuhnya diputuskan oleh Badan Hukum Syara'. Akan tetapi, kondisi menjadi berbeda setelah runtuhnya kesultanan dan tidak ada lagi lembaga yang mengawasi secara langsung proses tradisi ini, maka masyarakat juga secara tidak langsung bertanggung jawab dalam mengawasi dan melestarikan tradisi Rimpu ini agar tidak punah.

Akan tetapi, diantara dua unsur di atas, peranan ulama sangat mendominasi dalam mengawasi penerapan syari'at Islam di Bima. Ulama di Bima berperan sebagai seseorang yang melakukan interpretasi ajaran agama, sehingga mampu mengubah cara pandang dan sikap masyarakat. Istilah ini diperkenalkan oleh Geetz dalam bukunya "The Javanese Kijaji : The Changing Role of Cultural Broker" sebagai cultural broker. ${ }^{59}$

${ }^{59}$ Clifford Geertz, seorang Antropolog, melihat peran kyai/ulama (dalam hal ini kyai Jawa) sebagai 
Ketika maklumat resmi dari sang sultan tentang kewajiban ber-Rimpu bagi seluruh perempuan mbojo dikeluarkan, para staf kesultanan dibantu para ulama membantu mensosialisasikan hal ini kepada masyarakat. Maklumat ini disampaikan secara lisan dan tulisan ditujukan kepada seluruh Lebe yang berada di Bima agar dapat menjalankan dan memberikan pemahaman masyarakat tentang tradisi ini. Di sini para ulama tidak hanya sekedar menyampaikan maklumat tersebut kepada masyarakat, tetapi juga memberikan interpretasi dan relevansi tradisi Rimpu dengan syari'at Islam. Salah satu interpretasi tersebut adalah bahwa tradisi Rimpu merupakan suatu bentuk implementasi dan ketaatan perempuan kepada Allah SWT. untuk menutup auratnya sebagaimana dalam Al-Qur'an dan Hadis. ${ }^{60}$

\section{SIMPULAN}

Dari uraian di atas, maka dapat disimpulkan beberapa poin sebagai berikut:

1. Rimpu merupakan pakaian tradisional perempuan Bima yang terdiri atas dua lembar sarung (Tembe Nggoli) yang mempunyai multi-fungsi, seperti sebagai pakaian penutup aurat berdasarkan AlQur'an dan Hadis; menghalangi dari sengatan matahari; serta, melindungi martabat dan kemulian perempuan. Umumnya, Rimpu terbagi menjadi dua macam, yakni Rimpu Mpida, yang digunakan oleh gadis yang belum menikah dengan seluruh bagian tubuh

agen yang membawa nilai baru bagi masyarakat Desa. Kyai tidak hanya berperan sebagai ustaz, akan tetapi juga memperkenalkan semangat modernitas khazanah budaya Islam, atau dalam bahasa sempitnya adalah perantara atau mediator budaya. Ade Sholihat, "The Cultural Broker and Alms : The Key Concepts to Understanding Turkish School in Indonesia" dipresentasikan dalam The $4^{\text {th }}$ International Conference on Indonesian Studies : Unity, Diversity, and Future, 54-55.

60 Wawancara dengan KH. Ghani Masykur, sesepuh ulama Bima, via telepon, tanggal 18 Desember 2015. tertutup kecuali kedua mata, dan Rimpu Colo/Tada yang digunakan oleh perempuan yang sudah berkeluarga dengan tubuh tertutup kecuali wajah. Akan tetapi, pada perkembangannya, fungsi dan pemakaian Rimpu menjadi sedikit 'bergeser'. Hal ini dikarenakan berbagai faktor, seperti masuknya kebudayaan asing, perkembangan fashion yang lebih up-to-date, dan lain-lain. Ketika pada masa Kesultanan Bima berjaya, Rimpu dikenakan oleh seluruh perempuan Mbojo (kecuali keluarga Bangsawan) sehari-hari. Meskipun pada saat ini, Rimpu masih tetap dipergunakan oleh masyarakat Mbojo, namun jumlahnya semakin berkurang, sehubungan dengan munculnya tren jilbab, hijab, dll. yang lebih praktis dan fashionable. Namun, sebagai upaya untuk melestarikan tradisi etnis Mbojo, Rimpu digalakkan pada acara-acara tertentu, seperti pawai kebudayaan, HUT Kota, dll.

2. Pemahaman masyarakat desa Ngali, kec. Belo, kab. Bima terhadap anjuran menutup aurat direalisasikan dalam bentuk tradisi memakai Rimpu yang merupakan tradisi turun-temurun sejak zaman kesultanan Bima berjaya. Pemaknaan tradisi tersebut tebagi kedalam 3 (tiga) lapis pemaknaan, antara lain:

a) Beberapa elemen penting yang harus ada dalam tradisi Rimpu, yaitu nilai etika berbusana sesuai syari'at (meliputi menutup aurat, melindungi martabat perempuan, dan tidak tipis atau membentuk badan) serta tata cara pemakaian Rimpu yang disepakati oleh masyarakat desa Ngali (yakni dengan menggunakan sarung sebagai alat/bahan untuk ber-Rimpu).

b) Motif atau manfaat tradisi ini diambil menurut pendapat lebe, budayawan, dan pemakai Rimpu. Motif yang diungkapkan tiap informan berbeda-beda. Ada yang 
memakai Rimpu karena merupakan budaya nenek-moyang yang harus dilestarikan, ada yang karena motif pakaian yang ekonomis dan praktis, dan ada pula yang murni memahami bahwa Rimpu diadaptasi dari konsep menutup aurat dalam Al-Qur'an maupun Hadis Nabi.

c) Rimpu hingga saat ini tetap dipergunakan oleh perempuan desa Ngali baik didalam maupun diluar rumah. Tidak hanya di desa Ngali, Rimpu juga tersebar di wilayah Daerah Tingkat II Bima pada umumnya dan kabupaten Dompu karena alasan budaya keserumpunan (suku Mbojo).

\section{DAFTAR PUSTAKA}

Al-Asfihani, Al-Ragib. Mu'jam Mufradat li al-Fäz Al-Qur'an. Beirut: Dar al-Fikr, t.th.

Al-Asqalani, Ibnu Hajar. Fath al-Bäri Syarh Sahih al-Bukhäri, terj. Amiruddin. Jakarta: Pustaka Azzam, 2008.

Al-Azhari, Muhammad bin Ahmad. Mu'jam Tahzib al-Lugah, Juz IV. Beirut: Dar alMa'rifah, 2001.

Al-Razi, Muhammad ibn Abi Bakar. Mukhtär al-Sihah, editor Mahmud Khatrabik. Beirut: Dar al-Fikr, 1973.

Al-Shabuni, Muhammad Ali. Rawa'i alBayā, juz II. Beirut: Dar al-Fikr, t.th.

Al-Qurthubi, Al-Jami' li Ahkàm al-Qur'ān, Juz XII. Beirut: Dar al-Kutub al-'Ilmiyyah, 1993.

'Atwah, Isma'il 'Abdul Fatah 'Abdul Kafi dan Fauzi Muhammad al-Sa'id. Huqūq alMar'ah fi al-Isläm. T.t.: Tabaqa Liqawāni al-Mulkiyyah al-Fikriyyah, t.th. . Alkitab, Cet. VIII. Jakarta: Lembaga Alkitab Indonesia, 2009.

Baz, Abdul Aziz bin dan Muhammad ibn Shalih al-Utsaimin, Hukum Hijab dan Cadar". Solo: Pustaka Mantiq, 1995.

Baalbaki, Rohi. Al-Mawrid : A Modern Arabic-English Dictionary, Cet. VII. Beirut: Dar el-Ilm Lilmalayin, 1995.
Baum, Gregory. Truth Beyond Relativism, terj. Achmad Murtajib. Yogyakarta: PT. Tiara Wacana Yogya, 1999.

Fahruddin, Fuad Mohd. Aurat dan Jilbab dalam Pandangan Mata Islam. Jakarta: Pedoman Ilmu Jaya, 1991.

Harahap, A. Salim. Sejarah Penyiaran Islam. Jakarta: t.tp, t.th.

Ismail, M. Hilir. Menggali Pusaka Terpendam : Butir-Butir Mutiara Budaya "Mbojo". Bima: t.tp, 2001.

Ismail, M. Hilir. Peran Kesultanan Bima dalam Perjalanan Sejarah Nusantara. Mataram: Penerbit Lengge, 2004.

Loir, Henri Chambert dan Siti Maryam R. Salahuddin (penyunting), Bo' Sangaji Kai : Catatan Kerajaan Bima, Edisi II. Jakarta: Yayasan Pustaka Obor Indonesia, 2012.

Mannheim, Karl. Ideology and Utopia : An Introduction to the Sociology of Knowledge. London: Routledge \& Kegan Paul LTD, 1954.

Manzur, Ibnu. Lisān al- 'Arab, Juz IV. Beirut: Dar al-Shadir, 1992.

Pangeran, Moh. Kisman. Dari Kontrak Panjang Hingga Musnahnya Istana dari Rakyat : Kisah Sultan Muhammad Menentang Korupsi. Bogor: Morinawa, 2013.

Raba, Manggaukang dan Mars Ansory Wijaya, Dompu : Dulu, Kinii dan Esok. Mataram: UD Bugenvil, 2002.

Rahman, M. Fachrir Islam di Bima : Kajian Historis tentang Proses Islamisasi dan Perkembangannya sampai Masa Kesultanan. Yogyakarta: Genta Press, 2008.Singke, MR Pahlevi Putra N.I. Salungka Pa'a : Ragam Hias Kain Tradisional Masyarakat Dompu Kultur Kain Tenun Songket Dompu. Lombok: CV Rossamari Sentausa, 2011.

Swidler, Leonard J. Woman in Yudaism : The Status of Women in Formatice Yudais. Metuchen: Scare Crow Press, 1978. 